\title{
Biblical appointments for the COVID-19 control
}

\section{Efraín Sánchez González}

University of Medical Science of Havana, Faculty of Medical Science "10 de Octubre"

Corresponding Author: Efraín Sánchez González, Asistant Professor, MD Fé Fernández Hernández Auxiliary Professor. University of Medical Science of Havana Faculty of Medical Science "10 de Octubre"

Received Date: October 30, 2020; Accepted Date: November 20, 2020; Published Date; November 23, 2020.

Citation: Efraín Sánchez, (2020) Biblical appointments for the COVID-19 control .Review Article J. Clin Case Rep and Stud. 1(7).

Doi: 10.31579/2690-8808/050

Copyright: () 2020 Efraín Sánchez González, This is an open-access article distributed under the terms of the Creative Commons Attribution License, which permits unrestricted use, distribution, and reproduction in any medium, provided the original author and source arecredited

\begin{abstract}
:
COVID-19 focuses the international strategic for the Public Health. The absence of a definitive treatment had carried to adopt several measures to control it. The biblical law affording leprosy is showing a defined epidemiologic strategic to control this illness. This strategy is focused in the value of the self-inquest, the importance from the scientific research, the useful from the social isolate, the hygiene role in the prevention and the gradual insertion into the society post illness. These elements are showing that the epidemiologic strategic contained in The Bible for the leprosy control is effectively applicable to the COVID-19 control.

Key words: COVID-19; control; Bible
\end{abstract}

\section{Background:}

Bible is a universal book. Many people consider it as a holy book. For others is just a book. Nevertheless both side are agree in the useful from it teaches. [1]

In the real context the COVID-19 control is focusing the main international health policy. This illness had been considered as epidemic beginning 2020. The no existence of an effective method to eliminate it had jumped the application of preventive epidemiologic strategies to contribute to the control of this illness. [2][3]

The biblical book "Leviticus" in the chapter 13 shows the health law for people from that time to control the leprosy. The absence of an effective treatment to eliminate this illness carried the application of an epidemiologic strategic for the leprosy control. [4]

Without take account the religious, philosophic or politic position, understand the main elements from this law may obtain important useful lessons for the COVID-19 control. [5]

Development: The biblical chapter previously referenced is formed by 59 verses. The verses $1-45$ show the main symptoms related to the leprosy. Also raise the priest role making the diagnostic of this illness.

These verses show that the whole population must know the leprosy symptoms. However the priest must be more suspicious being capable to differentiate between the leprosy symptoms and the symptoms from other similar illness.

The verse 46 it appoint because of itself importance for the leprosy control. This verse shows that a person who had been declared as leper must be isolated. This person must live out the camp. Thus it guarantees that may not spread to other persons.

The leprosy and the COVID-19 are illnesses that may spread without the physic presence from the ill person. The following verses until the last from this chapter show what to do with personal things polluted in leprosy. Once time identified the leprosy in personal things it must clean in water. If leprosy persist in these things it must eliminate by fire to eliminate any spread way. [6]

The chapter 14 continues showing several interesting measures for the leprosy control. When the leprosy symptoms had disappeared the priest must check the ill person in the isolate place.

If the priest identified the ill person as cured from leprosy the patient must extreme the hygienic measures and must be wholly shaved. By this way it eliminates any remainder from the illness in the patient hair.

Once time cleaned in sufficient water, the patient may enter to the camp but may not enter to it house during seven days more. This measure may the gradual insertion from the person to the society.

All these subjects are contained in the biblical epidemiologic strategic for the leprosy control. This strategic appoints the following elements.

The value of the self inquest. All society members must be relative with leprosy symptoms. They must contain sufficient epidemiologic culture to identify any leprosy symptom front of any skin damage. In the COVID19 control people must be large knowing the illness symptoms and consequences. [7]

The importance from the scientific research. The priest must identify the symptoms related with leprosy and differentiate from all skin illness. Thus should be possible a more effective leprosy control. The health people affording the COVID-19 must be epidemiologically sufficient to identify the COVID-19 from other illness with similar symptoms. [8]

The useful from the social isolate. The leper patient must be isolated socially. This measure should carries to reduce the spread possibilities and make single the epidemiologic observation to the patient. Controlling the 
COVID-19 the social isolate had been an effective measure to reduce the spread by this illness. [9]

The hygiene role in the prevention. The personal things sanitation from leprosy must be gradual agreeing to each case. In some cases should be sufficient the water use. In others the personal things must be fired. In both case excluding the personal things as spread cause may reduce the expansion and outbreak from the leprosy. In similar way it is important understand that COVID-19 can be expansive moreover than the ill person. Then, the hygiene from the whole context reduces the spread possibilities. [10]

The gradual insertion into the society. When the priest checked that the patient was free of leprosy the person might enter to camp but not to their house for seven days. This means that the patient couldn't be close to their parents during a week. In similar condition, the whole social insertion post COVID-19 must be gradual. Put limit to social relation when the patient is clinically saved reduces the spread when the patient isn't epidemiologically free of COVID-19. [11]

\section{Conclusions}

COVID-19 control is a main necessity in the present health context. The epidemiologic strategic contained in The Bible for the leprosy control is effectively applicable to the COVID-19 control.

\section{References}

1) Sociedades Bíblicas Unidas. Descubre La Biblia. Colombia, 2000.

2) Guanche Garcell H. (2020) COVID-19. Un reto para los profesionales de la salud. Revista Habanera de Ciencias Médicas; 19(2)
Serra Valdés MA. (2020) Infección respiratoria aguda por COVID-19: una amenaza evidente. Revista Habanera de Ciencias Médicas;19(1)

3) Sociedades Bíblicas Unidas en América Latina. Santa Biblia. Quinta Edición. Corea, 2018.

4) Morales Navarro D. (2020). Acciones del personal de salud del área estomatológica en relación a la COVID-19. Revista Cubana de Estomatología; 57(1)

5) Medina-Fuentes G, Carbajales León EB, Figueredo González Y, Carbajales León AI, Silva Corona I. et.al. (2020) Características clínico epidemiológicas de pacientes positivos a la COVID-19 pertenecientes al policlínico "Joaquín de Agüero y Agüero" Camagüey. Revista Electrónica Dr. Zolio E. Marinello Vidaurreta; 45(4)

6) Cobas Planchez L, Mezquia de Pedro N, Saul Segundo Armenteros Terán SS. (2020). Características clínicas de pacientes con sospecha de COVID-19 ingresados en el hospital "Frank País García", La Habana. Revista Electrónica Dr. Zolio E. Marinello Vidaurreta; 45(4)

7) Urquiza Yero Y., Pérez Ojeda M.D., Cortés González A.M., Isabel Escalona Pérez I., Cabrales León M.O.

8) Falcón Hernández A, Navarro Machado V.R, Díaz Brito A, Delgado Acosta H. M, Valdés Gómez M. L. (2020). Pesquisa activa masiva poblacional para la COVID-19. Experiencia con estudiantes de las ciencias médicas. Cienfuegos, MEDISUR; 18(3)

9) Ribot Reyes V.C, Chang Paredes N, González Castillo A.L. (2020). Efectos de la COVID-19 en la salud mental de la población. Revista Habanera de Ciencias Médicas; 19(1)

10) Núñez Herrera A.C, Fernández Urquiza M, González Puerto $Y$, Gaimetea Castillo C.R, Rojas Rodríguez Y, et.al (2020) Resultados de la capacitación sobre la COVID-19. Universidad de Ciencias Médicas de Cienfuegos MEDISUR; 18(3) 